\title{
Antidiabetic Activity of Flavonoid from Binahong Leaves (Anredera cordifolia) Extract in Alloxan Induced Mice
}

Ratna Djamil ${ }^{1}$, Wiwi Winarti ${ }^{1}$, Sarah Zaidan ${ }^{2}$ and Syamsudin Abdillah ${ }^{2}$

${ }^{1}$ Department of Biology of Pharmacy, Faculty of Pharmacy, Pancasila University, Jakarta, Indonesia

${ }^{2}$ Department of Pharmacology, Faculty of Pharmacy, Pancasila University, Jakarta, Indonesia

*Corresponding author: Syamsudin Abdillah, Department of Pharmacology, Pancasila University, Jakarta, Indonesia, Tel: +6221-7864728; E-mail: syamsudin@univpancasila.ac.id

Received date: Jul 03, 2017; Accepted date: Sep 08, 2017; Published date: Sep 12, 2017

Copyright: @ 2017 Abdillah S, et al. This is an open-access article distributed under the terms of the Creative Commons Attribution License, which permits unrestricted use, distribution, and reproduction in any medium, provided the original author and source are credited.

\begin{abstract}
Objective: To evaluate antidiabetic activitiy of flavonoid from binahong (Anredera cordifolia) leaves.

Method: a-glycosidase enzyme inhibiting activity was tested in vitro and antidiabetic activity in alloxan-induced mice.

Results: The research shows that ethyl acetate extract of binahong leaves had $\alpha$-glycosidase enzyme inhibition of $81,23 \mu \mathrm{g} / \mathrm{mL}$. Isolation of active compounds in binahong leaves successfully identified flavonoid compound of 8Glucopyranosyl-4',5,7-trihydroxyflavone, which is also known as 8-Glucopyranosylapigenin. 8-Glucosylapigenin that is also popularly known as Orientoside was found to have $\alpha$-glycosidase enzyme inhibiting activity with $I_{50}$ value of $20,23 \mu \mathrm{g} / \mathrm{mL}$ and have an ability to decrease blood glucose in alloxan-induced mice.

Conclusion: Ethyl acetate extracts of binahong (Anredera cordifolia) leaves contain flavonoid compound of 8Glucopyranosyl-4',5,7-trihydroxyflavone, which is also known as 8-Glucopyranosylapigenin, 8-Glucosylapigenin, which is able to decrease blood glucose and inhibit enzim a-glycosidase enzyme.
\end{abstract}

Keywords: Antidiabetic activity; Binahong (Anredera cordifolia) leaves; $\alpha$-glycosidase inhibition

\begin{abstract}
Abbreviations:
DC: Diabetic Control; LD $_{50}$ : Medium Lethal Dose; BW: Body Weight.

\section{Introduction}

Diabetes mellitus is a syndrome characterized by chronic hyperglycemia and metabolic disorders of carbohydrate, protein, and fats related to a deficiency in the insulin secretion by pancreas- $\beta$ cell or a deficiency in the insulin action [1]. Diabetes mellitus remains a national health problem and ranks the fourth in the priority of national research on degenerative diseases. It was estimated that 1.4 cases of diabetes mellitus occur in Indonesia annually [2,3].
\end{abstract}

Indonesia had more than 7,000 types of plants, and more than 1,000 types of them have been used as traditional medicine by the local communities in Indonesia [4,5]. This is particularly true during the last 10 years. Some factors that might contribute to the increasing interest in using the traditional medicine is because the medicinal plants are believed to have certain properties and they are safe, easily available, and less expensive alternatives to modern medicine [4].

As a mega diverse nation, Indonesia is rich in biodiversity of natural resources. One of the native plants from Indonesia that has been widely used for diabetes is binahong (Anredera cordifolia (Ten.) Steenis), known as Dheng San Chi in China. In Europe, it is popularly known as heartleaf madeiravine and in South America is known as medeira-vine [6]. A research conducted by Sukandar et al. [7] found that methanolic extracts of binahong ( $A$. cordifolia (Ten.) Steenis) leaves at dosages of 50,100 , and $200 \mathrm{mg} / \mathrm{kg} \mathrm{BW}$ were found to be able to decrease blood glucose. Variation in the blood glucose decrease showed improvement in the damaged pancreatic $\beta$-cells of the mice at the dosages of 50 and $200 \mathrm{mg} / \mathrm{Kg} \mathrm{BW}$, compared to those in the positive control group $(\mathrm{p}<0.05)$. Therefore, the aim of the study was to evaluate the antidiabetic activitiy of flavonoid from binahong $(A$. cordifolia) leaves in Alloxan Induced Mice.

\section{Material and Methods}

\section{Plant materials}

Plant materials were obtained from the Research Institute for Spice, Bogor, Indonesia. The samples were identified by the Research Centre for Biology, Indonesian Institute of Science. The sample was rinsed with clean water, and then was sliced into small pieces and stored in drying chamber. The dried sample was grinded into powder.

\section{Preparation of extracts}

Four kilograms of binahong leaf dried powder were extracted with gradual maceration using ethanol for 7 respective days until perfect extracts were obtained. The solution was stirred continuously during the submersion. The resulting macerate was collected; the eluent was evaporated using a vacuum rotary evaporator to obtain a crude ethanolic extract, which was then partitioned. The crude ethanolic 
extracts were then consecutively partitioned with $n$-hexane, ethyl acetate, and n-butanol.

\section{Isolation and identification of active compounds}

Isolation of active compounds was conducted for ethyl acetate extract using Vacuum Solution Chromatography and motile phase of silica gel 60. Elution was obtained using the dichloromethaneisopropanol-methanol mixture in a gradient way. The isolate was identified by the structure using core magnetic, resonance spectrometric measurements of ${ }^{1} \mathrm{H}-\mathrm{NMR},{ }^{13} \mathrm{C}-\mathrm{NMR}, 2 \mathrm{D}-\mathrm{NMR}$, Ultra Violet-Visible (UV-Vis), Infra-Red (IR), Liquid Chromatography-Mass Spectrometry (LC-MS) [8].

\section{Alpha-Glycosidase inhibition assay}

a-Glycosidase inhibitory activity was assessed according to the methods described by Andrade-Cetto et al. [8,9] with minor modifications. Briefly, the enzyme reaction was performed using pNitrophenyl-alpha-D-glucopyranoside (PNP-glycoside) as a substrate in $0.1 \mathrm{M}$ piperazine- $\mathrm{N}, \mathrm{N}^{\prime}$-bis (2-ethanesulfonic acid) (PIPES) buffer, $\mathrm{p}^{\mathrm{H}}$ 6.8. The PNP-glycoside $(2.0 \mathrm{mM})$ was premixed with samples at various concentrations. Each mixture was added to an enzyme solution (0.01 unit) to make $0.5 \mathrm{ml}$ of the final volume. The reaction was terminated by adding $1 \mathrm{ml}$ of $0.64 \% \mathrm{~N}$-(1-naphthyl) ethylenediamine solution $\left(\mathrm{p}^{\mathrm{H}}\right.$ 10.7). Enzymatic activity was quantified by measuring the p-nitrophenol released from PNP-glycoside at $405 \mathrm{~nm}$ wave length. All reactions were carried out at $37^{\circ} \mathrm{C}$ for $30 \mathrm{~min}$ with three replications. Acarbose was used as a positive control. One set of mixtures prepared with an equivalent volume of PIPES buffer instead of tested samples was used as a control. The concentration of the extracts required to inhibit $50 \%$ of $\alpha$-glucosidase activity under the assay conditions was defined as the $\mathrm{IC}_{50}$ value.

\section{Antidiabetic activity}

Thirty ICR Mice were randomized into six groups such that group A non-diabetic received orally $0.5 \mathrm{ml}$ of distilled water, three times a day for 10 days (Preliminary studies revealed that the untreated diabetic rats could survive up till the $12^{\text {th }}$ day; therefore, our experiment was terminated shortly before their death). Animals in groups B, C, D, E and $\mathrm{F}$ which were made diabetic with alloxan $(250 \mathrm{mg} / \mathrm{kg}$ b.w) received $0.5 \mathrm{ml}$ of distilled water, the same volume of acarbose $(40 \mathrm{mg} / 100 \mathrm{~g})$, 10,50 and $100 \mathrm{mg} / \mathrm{kg}$ b.w of the Orientoside respectively.

\section{Statistical analysis}

All the values of body weight, fasting blood sugar, and biochemical estimations were expressed as mean \pm Standard Error of Mean (SEM) and analyzed using student ' $\mathrm{t}$ ' test.

\section{Results}

\section{Fractionation of binahong leaves extract}

Binahong ( $A$. cordifolia (Ten.) Steenis) leaves were sorted for the research and 4 kilograms were extracted using ethanol in maceration way to produce 732,815 grams of dark-green thick ethanolic extract. Non-polar, semi-polar, and polar fractions were, respectively, fractionated using n-hexane, ethyl acetate, and n-buthanol eluents. The fractionation resulted in 152.6 grams of n-hexane extract, 72.4 grams of ethyl acetate extract, and 55.61 grams of n-buthanol extract.

\section{Identification of active compound}

Due to relatively good $\alpha$-glycosidase enzyme inhibition activity, the ethyl acetate extract was followed up with isolation process and identification of the compounds found in the ethyl acetate extracts was done in a chromatographic way using the mixture of dichloromethane, isopropanol and methanol eluents in a gradient way. Fractions that had similar chromatogram patterns and $\mathrm{R}_{\mathrm{f}}$ value were combined. The 6 fractions were further isolated with sephadex column chromatography using methanol eluent and then purified using column chromatography to obtain isolate EA6. The structure of compounds isolated from binahong ( $A$. cordifolia) leaves were then determined. The NMR and MS data were obtained for compound. Based on the spectral analysis of UV-Vis, IR, ${ }^{1} \mathrm{H}-\mathrm{NMR},{ }^{13} \mathrm{C}-\mathrm{NMR}$, it can be concluded that EA6 is a 8-Glucopyranosyl-4',5,7-trihydroxyflavone compound, which is also called 8-Glucopyranosylapigenin, 8Glucosylapigenin as well as Orientoside (Figure 1).

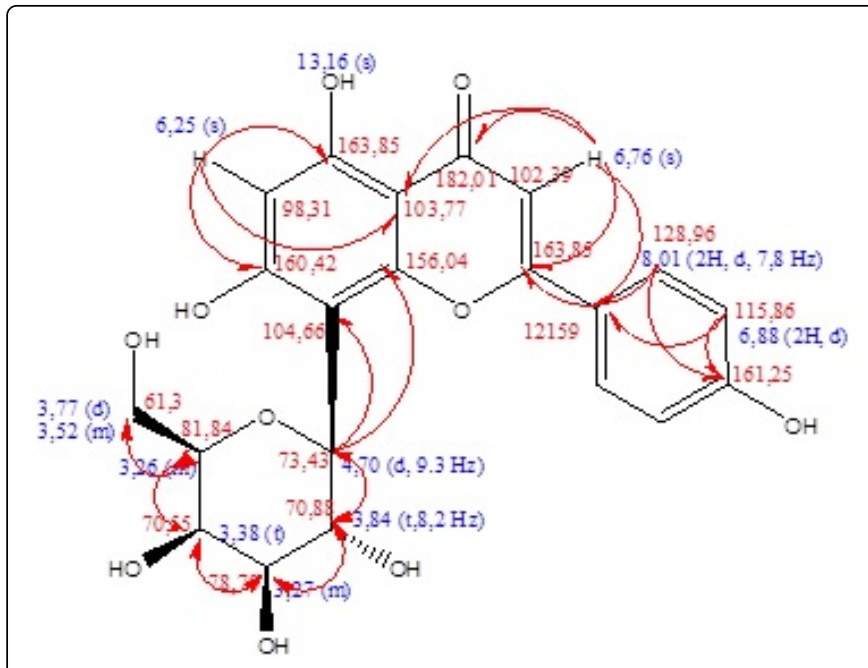

Figure 1: Structural illustration for Aromatic Frame of Isolate EA6.

\begin{tabular}{|l|l|}
\hline Compounds & $\mathbf{I C}_{50}(\boldsymbol{\mu g} / \mathbf{m L})$ \\
\hline Ethyl acetate fraction & 81.23 \\
\hline Isolate -1 & 67.50 \\
\hline Isolate-2 & 106.72 \\
\hline Isolate-3 & 59.63 \\
\hline Isolate-4 & 111.96 \\
\hline Isolate-5 & 298.23 \\
\hline Isolate EA6 & 20.23 \\
Acarbose & 102.34 \\
\hline
\end{tabular}

Tabel 1: $\alpha$ - glucosidase inhibitory effect of active compounds from Binahong leaves Extract.

The signals identified at the chemical area of $\delta \mathrm{H} 13,16\left({ }^{1} \mathrm{H}, 5-\mathrm{OH}\right.$, s) revealed an intra-molecular hydroxyl group that forms a hydrogen bond with $\mathrm{O}$ in the carbonyl group $(\mathrm{C}=\mathrm{O})$, as presented in Part $\mathrm{A}$ and $B$ in the structure. In addition, there are 2 aromatic protons in singlet 
form, which appeared at $\delta \mathrm{H} 6,25\left({ }^{1} \mathrm{H}, \mathrm{H}-6, \mathrm{~s}\right)$ and $6,76\left({ }^{1} \mathrm{H}, \mathrm{H}-3, \mathrm{~s}\right)$. This shows that both protons were located in different rings. $\alpha$ glucosidase inhibition of active compound of Binahong leaves. Table 1 represents the results of $\alpha$-glycosidase inhibition assay in the 6 isolates and ethyl acetate fraction.

Table 1 shows that orientoside, a flavonoid isolated from the extracts of binahong leaves, had more powerful a-glycosidase inhibiting activities than those of other compounds and acarbose. Isolate EA6 was found to be the strongest in inhibiting the $\alpha$ glycosidase enzyme, with an $\mathrm{IC}_{50}$ value of $20.23 \mu \mathrm{g} / \mathrm{mL}$, compared to any other isolates as well as acarbose, which had an $\mathrm{IC}_{50}$ value of $102.34 \mu \mathrm{g} / \mathrm{mL}$.

\section{Antidiabetic activity of active compounds from Binahong leaves Extract}

A fasting blood glucose level of all animals before treatment was within the normal range (Table 2). Fasting glucose levels was significantly elevated after $24 \mathrm{~h}$ of alloxan injection with respect to control level.

\begin{tabular}{|l|l|l|l|l|}
\hline Fasting blood sugar level (mg/dL-1) & At the time of grouping & \multicolumn{3}{l|}{} \\
\hline Group & & $\mathbf{0}$ days of active compounds supplementation \\
\hline Diabetic & $234 \pm 45$ & $232 \pm 67$ & $\mathbf{7}$ day & $\mathbf{1 4}$ day \\
\hline Isolate EA6 $10 \mathrm{mg} / \mathrm{kg} \mathrm{BW}$ & $267 \pm 78$ & $245 \pm 87$ & $226 \pm 68$ & $219 \pm 154$ \\
\hline Isolate EA6 $50 \mathrm{mg} / \mathrm{kg} \mathrm{BW}$ & $309 \pm 110$ & $305 \pm 138$ & $236 \pm 78$ & $223 \pm 120$ \\
\hline Isolate EA6 $100 \mathrm{mg} / \mathrm{kg} \mathrm{BW}$ & $260 \pm 82$ & $250 \pm 59$ & $301 \pm 121$ & $186 \pm 119$ \\
\hline Acarbose $40 \mathrm{mg} / 100 \mathrm{~g}$ & $312 \pm 101$ & $310 \pm 82$ & $103 \pm 87$ & $80 \pm 21$ \\
\hline
\end{tabular}

Table 2: Effect of active compounds from Binahong leaves Extract after 7 days and 14 days treatment on blood sugar level in alloxan-induced diabetic male mice.

The administration of isolate EA6 for 7 days for all dosage groups was not able to decrease the blood glucose concentration to the normal level. Only the dosage $100 \mathrm{mg} / \mathrm{kg}$ BW administration for 14 days could decrease the blood glucose concentration to the same levels as the normal group and acarbose $(\mathrm{p}<0.05)$.

\section{Conclusion}

Anredera is one species of the Basellaceae which empirically has many benefits in health, especially for treating various diseases. Familia Basellaceae have a variety of species such as Anredera baselloides (Kunth) Baill, Anredera cordifolia (Ten.) Steenis, Anredera diffusa (Moq.), Anredera leptostachys (Moq.)Steenis, Anredera spicata, Anredera vesicaria, Anredera cumingii, and others [10]. One species that is widely used by people in Indonesia are Anredera cordifolia locally known as "binahong".

Binahong plant contains saponins, alkaloids, polyphenols, flavonoid and monopolysaccharide including L-arabinose, D-galactose, Lrhamnose, D-glucose are among the most common components of the attached chains. These plants also have a high compound of flavonoid from leaves, stems, tubers and flowers [11].

Isolation of active compounds from ethyl acetate extracts of binahong leaves based on bioassay guided fractionation for in vitro $\alpha$ glycosidase inhibition revealed that, isolated AE6 had a powerful $\alpha$ glycosidase inhibiting activities, with an $\mathrm{IC}_{50}$ value of $20.23 \mu \mathrm{g} / \mathrm{mL}$, compared to those of other isolates and acarbose as a positive control (Table 1). This confirms that bioactive compounds in ethyl acetate extract of binahong leaves works as a a-glycosidase enzyme inhibitor, as acarbose does. A study conducted by Afproli et al. [12] isolated phenol compound from Polygonum hyrcanicum. The study, which was guided by a-glycosidase inhibition assay, found thirteen phenolic compounds, including a cinnamoyl phenethyl amide, two flavones, ten flavonols and flavonol 3-O-glycosides that were subsequently isolated from the extract. Comparison of the $\mathrm{IC}_{50}$ values of tested flavonoids showed that hydroxyl substitution affected the inhibitory activity so that, increasing number of free phenolic groups results in higher activity.

Identification of chemical structure of isolate EA6 based on spectrometric data of FT-IR, GC-MS and NMR, compared to literature data, shows that isolate EA6 is a 8-Glucopyranosyl-4',5,7trihydroxyflavone compound, which is also called 8Glucopyranosylapigenin [8]. Ishikawa et al. [12] studied the inhibition of $a$-glucosidase by various poly phenolic compounds. Among the compounds tested, quercetin, catechin and epicatechin were reported to inhibit $\alpha$-glycosidase strongly when compared to apigenin, indicating that presence of two hydroxyl groups in B ring is necessary for strong inhibition of $\alpha$-glucosidase. Tadera et al. [13] have studied the inhibition of $\alpha$-glucosidase and $\alpha$-amylase by natural flavonoids and has shown that, the presence of hydroxyl group at C-3 position of flavone enhanced the inhibitory activity (quercetin>luteolin; kaempferol $>$ apigenin) and they have also reported that the presence of more than two hydroxyl groups in B ring inhibits $\alpha$-glucosidase more effectively.

In vivo antidiabetic assay for isolate EA6, using alloxan-induced male mice, showed that at dosages of 50 and $100 \mathrm{mg} / \mathrm{kg} \mathrm{Bw}$, isolate EA6 was found to be able to decrease blood glucose at a level that was comparable to the effect of $40 \mathrm{mg} / \mathrm{kg} \mathrm{BW}$ of acarbose. Alloxan is used to induce diabetes, since it is a diabetogenic compound, which works by damaging $\beta$ pancreatic cells, thus reducing insulin secretion by means of $\beta$ pancreatic cells [14]. Diabetogenic effect of alloxan is attributable to core DNA fragmentation by a reactive compound. The damage will extend to poli activity (ADP ribose) of synthase, depletion 
of intracellular NAD+ and eventually lead to cellular death. Isolate EA6 (8-Glucopyranosylapigenin) was found to be able to decrease blood glucose in hyperglycemic mice, thanks to the inhibition of $\alpha$ glycosidase as acarbose did. A study conducted by Sangupta et al. [15] showed that bioactive compounds in Tinospora cordifolia as saponarin (apigenin-6-C-glucosyl-7-O-glucoside) had in vitro a-glycosidase inhibiting activity and saponarin showed hypoglycemic activity in the range of $20-80 \mathrm{mg} / \mathrm{kg}$ compared to $100-200 \mathrm{mg} / \mathrm{kg}$ for acarbose as reported [16-19].

\section{Ethics Approval}

The study was carried out after approval from the Department Ethical Committee on the Use and Care of Experimental Animals.

\section{Authors Contributions}

Ratna Djamil, Wiwi Winarti and Sarah Zaidan prepared the manuscript and Syamsudin Abdillah edited it.

\section{Acknowledgement}

Thanks to Simlitabmas DIKTI for providing research fund through of Hibah Bersaing 2015/2016.

\section{References}

1. Thuillier P, Alavi Z, Kerlan V (2015) Long-term safety and efficacy of insulin degludec in the management of type 2 diabetes. Diabetes, metabolic syndrome and obesity: targets and therapy $8: 483$.

2. Mihardja L, Manz HS, Ghani L, Soegondo S (2009) Prevalence and determinants of diabetes mellitus and impaired glucose tolerance in Indonesia (a part of basic health research/Riskesdas). Acta Medica Indonesiana 41: 169-174.

3. International Diabetes Federation: IDF Diabetes Atlas. 5th edition. Brussels, Belgium: International Diabetes Federation 2010.

4. Woerdenbag HJ, Kayser O (2014) Jamu: Indonesian traditional herbal medicine towards rational phytopharmacological use. J Herb Med 4: 51-73.

5. Kadir MF, Karmoker JR, Alam MR, Jahan SR, Mahbub S (2015) Ethnopharmacological survey of medicinal plants used by traditional healers and indigenous people in Chittagong Hill tracts, Bangladesh, for the treatment of snakebite. Evid Based Complement Alternat Med 2015.

6. Chuang MT, Lin YS, Hou WC (2007) Ancordin, the major rhizome protein of madeira-vine, with trypsin inhibitory and stimulatory activities in nitric oxide productions. Peptides 28: 1311-1316.
7. Sukandar EY, Qowiyyah A, Larasari L (2013) Effect of Methanol Extract Hearhleaf Madeiravine (Anredera cordifolia (Ten.) Steenis) Leaves on Blood Sugar in Diabetes Mellitus Model Mice. J Med Planta 1:4.

8. Andrade-Cetto A, Becerra-Jiménez J, Cárdenas-Vázquez R(2008) Alfaglucosidase-inhibiting activity of some Mexican plants used in the treatment of type 2 diabetes. J Ethnopharmacol 116: 27-32.

9. Abou-Zeid AHS, Soliman FM, Sleem AA, Mitry MNR (2007) Phytochemical and bio-activity investigations of the aerial parts of Anredera cordifolia (Ten.) Steenis. Bull Nat Res Cent Egypt Cairo 32: 31-33.

10. Moradi-Afrapoli F, Asghari B, Saeidnia S, Ajani Y, Mirjani M, et al. (2012) In vitro a-glucosidase inhibitory activity of phenolic constituents from aerial parts of Polygonum hyrcanicum. DARU J Pharm Sci 20: 37.

11. Sari BR, Sarjito, Haditomo C (2015) The Added Effect of Binahong Leaves Powder (Anredera cordifolia) on Food toward Survival Rate and Histopathology of Vannamei (Litopenaeus vannamei) Infected by Vibrio harveyi. J Aquac Mgmt Tech 4: 26-32.

12. Ishikawa A, Yamashita H, Hiemori M, Inagaki E, Kimoto M, et al. (2007) Characterization of inhibitors of postprandial hyperglycemia from the leaves of Nerium indicum. J Nutr Sci Vitaminol 53: 166-173.

13. Tadera K, Minami Y, Takamatsu K, Matsuoka T (2006) Inhibition of $\alpha-$ glucosidase and $\alpha$-amylase by flavonoids. J Nutr Sci Vitaminol 52: 149-153.

14. Oloyede HOB, Bello TO, Ajiboye TO, Salawu MO (2015) Antidiabetic and antidyslipidemic activities of aqueous leaf extract of Dioscoreophyllum cumminsii (Stapf) Diels in alloxan-induced diabetic rats. J Ethnopharmacol 166: 313-322.

15. Sengupta S, Mukherjee A, Goswami R, Basu S (2009) Hypoglycemic activity of the antioxidant saponarin, characterized as a-glucosidase inhibitor present in Tinospora cordifolia. J Enzyme Inhib Med Chem 24: 684-690.

16. Ban K, Hui S, Drucker DJ, Husain M (2009) Cardiovascular consequences of drugs used for the treatment of diabetes: potential promise of incretin-based therapies. J Am Soc Hypertens 3: 245-259.

17. Elya B, Handayani R, Sauriasari R, Hasyyati US, Permana IT, et al. (2015) Antidiabetic activity and phytochemical screening of extracts from indonesian plants by inhibition of alpha amylase, alpha glucosidase and dipeptidyl peptidase IV. Pak J Biol Sci 18: 279.

18. Sukandar EY, Qowiyyah A, Larasari L (2013) Effect of Methanol Extract Hearhleaf Madeiravine (Anredera cordifolia (Ten.) Steenis) Leaves on Blood Sugar in Diabetes Mellitus Model Mice. J Planta Med 1: 4.

19. Espada A, Rodriguez J, Villaverde MC, Riguera R (1990) Hypoglucaemic triterpenoid saponins from Boussingaultia baselloides. Can J Chem 68: 2039-2044. 